\title{
Epidermolyticus ichthyosis
}

\section{Epidermolytic ichthyosis}

\author{
CSOMA ZSANETT RENÁTA DR. ${ }^{1}$, MARI JUDIT DR. ${ }^{2}$, FRANCZIA PÉTER DR. ${ }^{2}$, \\ VARGA ERIKA DR. ${ }^{1}$, KEMÉNY LAJOS DR. ${ }^{1,4}$, NAGY NIKOLETTA DR..$^{1,3,4}$ \\ Bőrgyógyászati és Allergológiai Klinika, Szegedi Tudományegyetem¹ ${ }^{1}$ Szeged \\ Gyermekgyógyászati Klinika és Gyermek Egészségügyi Központ, Szegedi Tudományegyetem², \\ Szeged \\ Orvosi Genetikai Intézet, Szegedi Tudományegyetem³ ${ }^{3}$, Szeged \\ MTA-SZTE Dermatológiai Kutatócsoport ${ }^{4}$, Szeged
}

\section{ÖSSZEFOGLALÁS}

A hólyagképződéssel járó, epidermolysis bullosa betegségcsoportba tartozó kórképek, illetve a veleszületett elszarusodási zavarok, az ichthyosisok gyakran már újszülöttkorban igen súlyos, kiterjedt bőrgyógyászati manifesztációkkal jelentkezhetnek. Az epidermális barrier funkció jelentoos fokú károsodása számos élettani következménnyel jár, ezek közé tartozik a folyadék-elektrolit háztartás, a hóháztartás egyensúlyának felborulása és a nagyfokú infekcióhajlam is. Ezen genodermatosisokban szenvedő újszülöttek intenzív osztályos ápolást igényelnek.

Az újszülött egy napos életkorban, kardiorespiratórikusan stabil állapotban került felvételre az SZTE ÁOK Gyermekgyógyászati Klinika Neonatális Intenzív Osztályára. Felvételekor testszerte, generalizáltan változó nagyságú, helyenként konfluáló, felszínesen hámfosztott területeket észleltünk lesodródott hólyagfedelekkel. A klinikai tünetek, a kiterjedt denudáció alapján elsôdlegesen epidermolysis bullosa betegségcsoportba tartozó kórkép fennállásának lehetôsége merült fel. Helyi hámosító, hidratáló, emolliens kezelés bevezetése mellett a hámfosztott területek reepitelizációja megfelelô ütemben zajlott. A reepitelizációt követôen testszerte kifejezett bőrszárazság, helyenként pikkelyes hámlást mutató hyperkeratotikus tünetek kialakulását észleltük, amely alapján felmerült a keratinopathiás ichthyosisok csoportjába tartozó kórkép fennállásának lehetősége is; a szövettani vizsgálat megerôsítette a klinikai diagnózist. A gyermek gondozása jelenleg az SZTE ÁOK Bőrgyógyászati és Allergológiai Klinika Gyermekboórgyógyászati Szakrendelésén történik.

\section{Kulcsszavak:}

epidermolyis bullosa - denudáció - Neonatális Intenzív Centrum - epidermolyticus ichthyosis - KRT1 és KRT10 mutáció - lokális keratolitikus kezelés - szisztémás retinoid terápia

\section{SUMMARY}

Patients suffering from hereditary blistering disorders or hereditary disorders of cornification may have severe cutaneous manifestations as early as in the neonatal period. The impairment of the epidermal barrier function results in numerous clinical consequences: high rate of transepidermal water loss, thermal instability and an increased susceptibility to systemic infections. These neonates require adequate intensive care during the first weeks of their life.

The authors present the case of a newborn female infant who was referred to the Neonatal Intensive Care Unit of the Department of Paediatrics, University of Szeged on the day after birth in stable cardiorespiratory condition. On admission, wide-spread, confluent, denuded, superficially eroded lesions of various extent and fragile superficial blisters were observed on the trunk, neck and the extremities. The clinical symptoms suggested epidermolysis bullosa as primary diagnosis. After the introduction of regular local epithelizing and emollient treatment, the reepithelization process was quick and adequate. Over time, skin fragility, the tendency of blister formation and erythroderma gradually decreased, and after reepithelization, dryness of the skin-and subsequentlyhyperkeratosis rather than blistering became the predominant clinical feature. The relevant cutaneous symptoms suggested the condition's proper classification the keratinopathic ichthyoses group of hereditary cornification disorders; histological examination confirmed the clinical diagnosis. The infant is being regularly followed up in the Paediatric Dermatology Outpatient Clinic at the Department of Dermatology and Allergology, University of Szeged.

Key words:

epidermolysis bullosa - denudation - Neonatal

Intensive Care Unit - epidermolytic ichthyosis - KRT1 and KRT10 mutations - local keratolytic treatment - systemic retinoid therapy

Levelező szerző: Csoma Zsanett Renáta dr. email: csoma.zsanett@med.u-szeged.hu 


\section{Esetismertetés}

Az újszülött első életnapján került felvételre az SZTE ÁOK Gyermekgyógyászati Klinika és Gyermek Egészségügyi Centrum Neonatális Intenzív Osztályára epidermolysis bullosa gyanúja miatt. A gyermek édesanyja 3., diabetes mellitussal szövődött terhességéból, 37. gesztációs hétre, 3100 grammal, Apgar 9/10 státuszban, per vias naturales született. Születést követôen légzési-keringési adaptációja zavartalan volt. A családban bőrbetegség, egyéb örökletes betegség nem fordult elő. Felvételekor testszerte, generalizáltan változó nagyságú, helyenként konfluáló, felszínesen hámfosztott területeket észleltünk lesodródott hólyagfedelekkel. Az újszülött a jelentős fokú denudáció miatt fájdalomcsillapítást igényelt (fentanyl, nalbuphin, ibuprofen). A klinikai tünetek, a kiterjedt denudáció alapján elsődlegesen epidermolysis bullosa betegségcsoportba tartozó kórkép fennállásának lehetősége merült fel.

Intenzív terápiás ellátásának elsố időszakában szaturáció esések miatt BiPAP (bilevel positive airway pressure), illetve nasalis CPAP (continuous positive airway pressure) légzéstámogatást igényelt. Öt napos életkorában a jobb véna jugularis interna kanülálásával centrális vénás hozzáférést biztosítottunk. Életének 10 . napján láz jelentkezett, a haemokultúrából Enterococcus faecalis tenyészett, emiatt célzottan Piperacillin/Tazobactam és Vancomycin kezelésben részesült. A nyaki centrális vénás kanül eltávolítását követően femorális centrális véna biztosítása, ennek rögzítései nehezítettsége miatt longline vénabiztosítás történt. Három hetes életkorban a gyulladásos paraméterek emelkedése miatt ismételt haemokultúra vizsgálat történt, Candida albicans tenyészett ki, emiatt parenterális fluconasol kezelésben részesült. Enterális táplálást kalória igényének megfelelően parenterális táplálással (aminosavak, szénhidrát, zsírok, elektrolitok, vitaminok, nyomelemek) egészítettük ki.

Systoles szívzöreje miatt kardiológiai szakvizsgálat történt, ez muscularis típusú, kis bal-jobb shunt-tel járó VSD-t véleményezett, melylyel akut kardiológiai teendô nem volt. Hasi UH vizsgálat bal oldalon 8x4 mm-es pyelontágulatot írt le. Újszülöttkori anyagcsere-szúrővizsgálatok megtörténtek, BCG oltást megkapta, hiányzó anyai HBsAg miatt Engerix-B oltásban részesült.

Helyi hámosító, hidratáló, emolliens kezelés bevezetése mellett a hámfosztott területek reepitelizációja megfelelő ütemben zajlott. A bőrtünetek miatt jelentős nehézséget okozott a perifériás és centrális vénás kanülök, szondák rögzítése, a hámfosztott területeken keresztüli infekciók kivédése és kezelése. Észlelésünk első időszakában folyamatosan jelentkeztek újabb hámfosztott területek, azonban kevésbé intenzív jelleggel. A reepitelizációt követően testszerte kifejezett bőrszárazság, helyenként pikkelyes hámlás mutató hyperkeratotikus tünetek kialakulását észleltük, amely alapján felmerült a keratinopathiás ichthyosisok csoportjába tartozó kórkép fennállásának lehetősége is. Az elvégzett szövettani

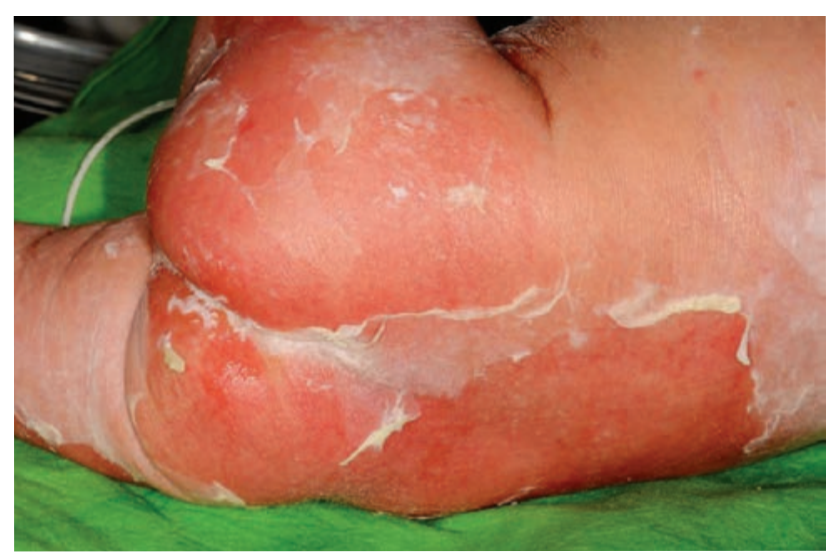

1a. ábra

Születést követően

testszerte kiterjedt denudáció volt észlelhető, lesodródott hólyagfedelekkel vizsgálat a hám felső rétegének részleges leválását és epidermolytikus hyperkeratosist mutatott, a klinikai tünetek alapján felmerült epidermolyticus ichthyosis diagnózisát megerôsítette. Az elvégzett genetikai vizsgálat során a kórkép hátterében leggyakrabban előforduló kódoló KRT1 (keratin 1) és KRT10 (keratin 10) géndefektusok szúrése történt meg a beteg perifériás vérmintájából izolált genomi DNS szekvenálásával. Az alkalmazott vizsgálati módszerrel a tünetek hátterében álló esetleges kóroki mutáció nem került azonosításra. A vizsgálattal ugyanakkor a KRT1 és KRT10 gén mutációk lehetôségét teljes mértékben nem lehet kizárni, mivel a gének nem kódoló régióinak - intronok, promoter régió, 3' és 5' át nem íródó régiók - vizsgálata nem történt meg, illetve az alkalmazott módszer csak egy vagy néhány nukleotidot érintố eltérés kimutatására képes, deléció, inzerció vagy egyéb átrendeződés detektálására nem alkalmas.

A csecsemôt 5 hetes életkorban, jó általános állapotban bocsájtottuk otthonába, ezt követően gondozását a Bơrgyógyászati és Allergológiai Klinika Gyermekbőrgyógyászati Szakrendelésén végezzük.

Három hónapos koráig észleltünk novum hámfosztott területek kialakulását. Jelenleg jellemzően mind a törzs, mind a végtagok területén lemezes hámlás, sárgásbarnás színú, morzsalékony, hyperkeratotikus plakkok fennállása figyelhetô meg.

\section{Megbeszélés}

A keratinopathiás ichthyosisokhoz tartozó epidermolyticus ichthyosis (Frost és Van Scott, ONIM: 6076029) igen ritka kórkép, előfordulási gyakorisága 1:200.000-1:300.000; általában autoszómális domináns öröklésmenet jellemzi. Régebbi nómenklatúra szerinti elnevezése bullosus kongenitális ichthyosiform erythroderma (Brocq), újszülöttkorban súlyos hólyagképződéssel, denudációval jár, kísérheti erythroderma is. A hólyagképződés az élet első heteiben igen jellegzetes tünet, a szuperficiális hólyagok mérete változó, akár több cm-es nagyságot is elérhet. A hámosodás üteme igen gyors, azonban bakteriális szuperinfekciók gyakran előfordulhatnak. Az életkor előrehaladtával a hólyagképződési hajlam és az erythroderma mértéke fokozatosan csökken; három hónapos kortól a hyperkeratosis klinikai tünetei jellegzetesek, eleinte a tünetek fóleg a térdek és a könyökök területén figyelhetőek meg, ezt követôen kiterjedtebbé válnak. Szürkés-barnás színú, téglafal szerü, morzsalékony, verrucosus,

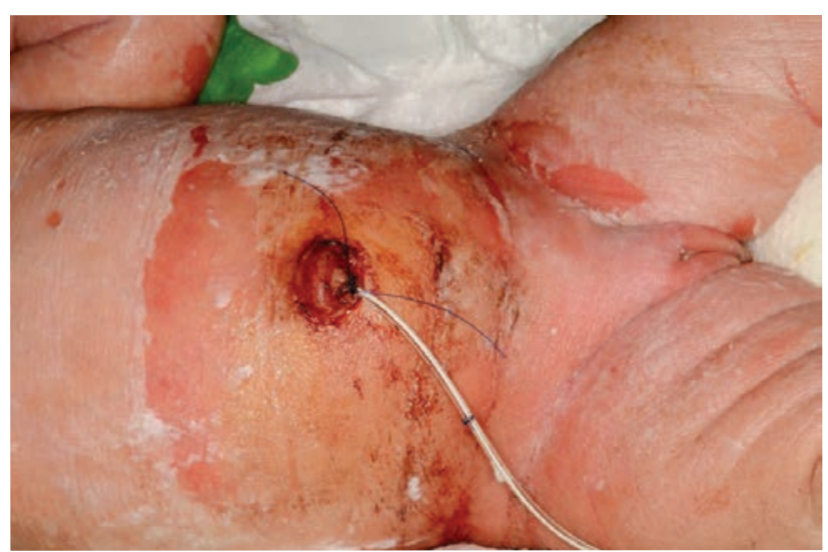

1b. ábra

A köldök vénás katéter rögzítésére szolgáló tapasz eltávolítását követôen kialakult fosztásos hámsérülés, felszínes erózió a has területén 


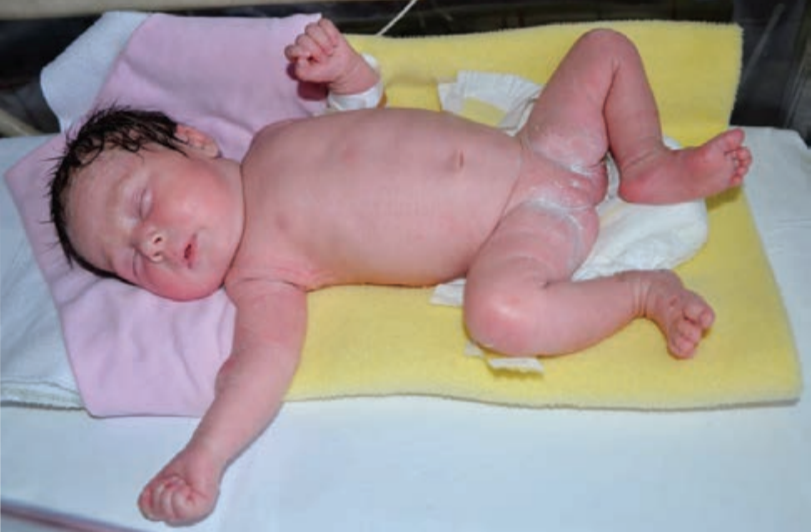

2. ábra

4 hetes kor: helyi hámosító, hidratáló, emolliens kezelés bevezetése mellett a hámfosztott területek reepitelizációja megfelelő ütemben zajlott

hyperkeratotikus, gyakran odorosus plakkok jelennek meg a flexurális redőkben és az intertriginosus területeken, jelentôsen rontva a betegek életminőségét. A bôr sérülékenysége, kisebb traumák hatására kialakuló eróziók és hólyagok az élet késóbbi szakaszában is megfigyelhetőek. A krónikus körömágygyulladás és a gyakori, recidiváló dermatophyton infekciók körömdystrophia kialakulásához vezethetnek. A tenyéri-talpi hyperkeratosis mértéke változó, a KRT1 gén mutációja esetén kifejezett $(1-5,7,8)$.

A betegséget a KRT1 (12q11-13) és a KRT 10 (17q1221) gének mutációi idézik elő (az esetek kb. 50 \%-ában de novo mutáció); mindkét fehérje az epidermis suprabasalis és granuláris rétegében expresszálódik. A keratin filamentumba beépülő fehérje kóros szerkezetú, a filamentumok funkciója károsodik, a cytoszkeleton instabilitását, az epidermis celluláris integritásának károsodását, kifejezett sérülékenységet, hólyagképződési hajlamot eredményez (1-6).

Szövettanilag kifejezett orthokeratotikus hyperkeratosis, acanthosis, a suprabasalis és granuláris sejtek cytolysise, intraepidermális hólyagképződés jellemzi. A keratinocyták kifejezett intracelluláris vakuolizációt mutatnak és vaskos keratin intermedier filamentumokat láthatunk. A dermis felsô részében enyhe fokú lymphohistiocytás infiltrátum lehet jelen.

Újszülöttkorban differenciál diagnosztikai problémaként elsôdlegesen az epidermolysis bullosa betegségcsoport merül fel; a pontos diagnózis felállításához elengedhetetlenül szükséges a szövettani és a genetikai vizsgálat elvégzése. Emellett a Staphylococcus forrázott bőr szindrómától, egyéb, vesiculobullosus tünetekkel járó infectióktól, illetve a toxicus epidermális necrolysistôl való elkülönítés fontos.

Későbbiek során elsôdlegesen az elszarusodási zavar dominál, emiatt a különféle ichthyosis formáktól szükséges elkülöníteni a kórképet. Az epidermolyticus ichthyosisok másik fő megjelenési formája a szuperficiális epidermolyticus ichthyosis (ichthyosis bullosa Siemens). A kórképre jellemzô a felszínesebb hólyagképzôdés, az elszarusodási zavar mértéke általában enyhébb, hátterében a keratin 2 gén

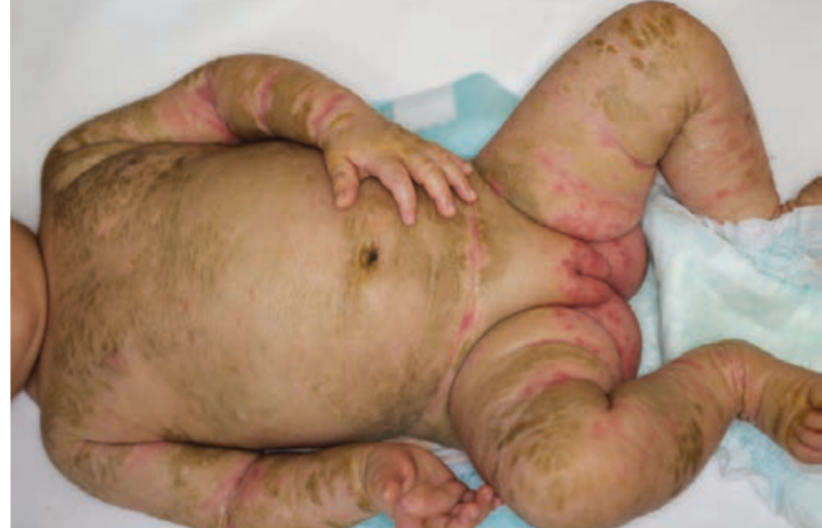

\section{3. ábra}

3 hónapos kor: mind a törzs, mind a végtagok területén lemezes hámlás, sárgásbarnás színú, morzsalékony, hyperkeratotikus plakkok fennállása figyelhető meg

mutációja áll (a gén által kódolt fehérje az epidermis magasabb rétegében expresszálódik). A KRT 1 és KRT 10 gének mutációi a következő kórképek kialakulását is eredményezhetik: annularis epidermolyticus ichthyosis, ichthyosis Curth-Macklin, illetve epidermalis naevus epidermolyticus hyperkeratotikus formája $(2-5,7,9)$.

A kezelés sajnálatos módon tüneti; a kezelés módja függ a betegség súlyosságától és a beteg életkorától. Az újszülöttek a kiterjedt denudáció és az epidermális barrier funkció jelentôs fokú károsodása miatt intenzív terápiás ellátást igényelnek. A vitális paraméterek monitorizálása, a folyadék-elektrolit és hôháztartás egyensúlyának fenntartása, az infekciós szövődmények megelőzése mellett kiemelkedősen fontos az adekvát helyi kezelések alkalmazása. A megfelelő emolliensek, hámosító készítmények, kötszerek használata mellett a hámosodás üteme általában gyors. Az újszülöttkori mortalitást és morbiditást leginkább a szeptikus szövődmények, valamint a folyadék-elektrolit háztartás felborulásának élettani következményei határozzák meg.

A későbbiekben a kezelés fő célja a hyperkeratosis és a hámlás mértékének csökkentése. Bázis terápiaként igen fontos a bôr rendszeres emolliens, hidratáló kezelése. Lokális dezificiensek, antiszeptikus szappanok, chlorhexidine tartalmú készítmények alkalmazása kedvezően befolyásolja a bakteriális kolonizációt és csökkenti a szuperinfekciók kialakulásának esélyét. A karbamid, szalicilsav, $\alpha$-hydoxy-savak, propylene-glycol tartalmú keratolitikumok hatékonyak, azonban gyakran nehezen tolerálhatóak, égô, viszketô érzést idézhetnek elő. A nagy mennyiségú, szalicilsav tartalmú externák alkalmazása kapcsán (különösen nagyobb testfelület esetén) figyelembe kell venni a szalicilát mérgezés kialakulásának potenciális lehetôségét is. A lokális calcipotriol és retinoid származékok alkalmazása során ugyancsak gyakori mellékhatás a helyi irritáció.

A szisztémás retinoid kezelés megfontolandó (kezdő dózis: $0,1 \mathrm{mg} / \mathrm{kg}$, fenntartó dózis: 0,5 mg/kg), az elszarusodási zavart kedvezóen befolyásolja, azonban a hólyagképződési hajlamot és a bôr sérülékenységét fokozza. A 


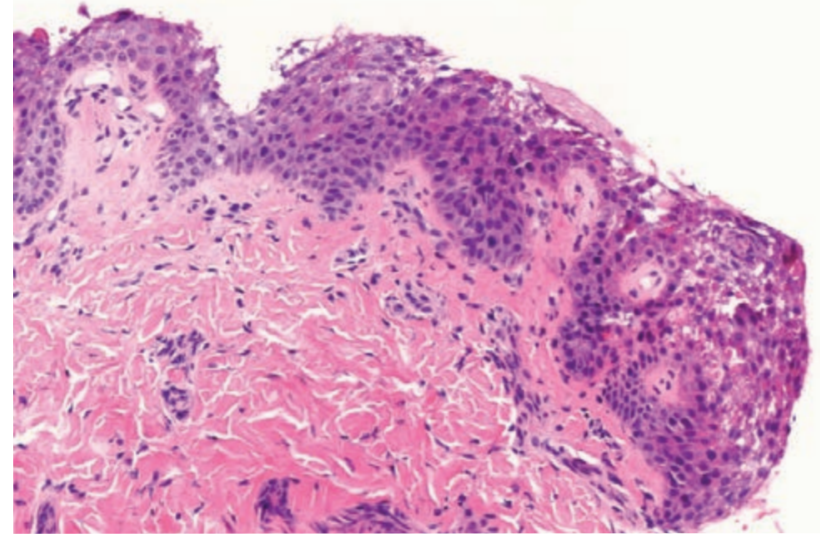

4. ábra

Szövettani kép: a hám felsô rétegének részleges leválása, hyperkeratosis, a dermis felsố rétegének vakuolizált degenerációja figyelhetô meg (formalin fixált paraffinba ágyazott anyag, hematoxilin-eozin festés, digitálisan rögzített metszetról készített 40 x-es nagyítás)

KRT10 mutáció esetén a retinoidokra adott válaszkészség kifejezetten jó (1-4).

Figyelembe véve a betegség krónikus természetét, fontos kiemelni, hogy a betegek egész életen át tartó gondozást igényelnek. A bőrgyógyászati kezelés mellett sok esetben pszichés életvezetés is szükséges. Az érintett családokban érdemes hangsúlyt fektetni a prenatális diagnózisra is.

\section{Köszönetnyilvánítás}

Dr. Csoma Zsanett Renáta a Magyar Tudományos Akadémia Bolyai János kutatási ösztöndíjában részesül (2015-2018).

\section{IRODALOM}

1. Braun-Falco's Dermatology (Eds.: Burgdorf W. H. C., Plewig G., Wolff H. H., Landthaler M.) 3rd ed. Heidelberg: Springer Medizin Verlag; 2009.

2. Harper's Textbook of Pediatric Dermatology. (Irvine A. D., Hoeger P. H., Yan A. C.) 3rd ed.Wiley-Blackwell, 2011.

3. Hurwitz Clinical Pediatric Dermatology (Eds.: Paller A. S., Mancini A. J.) 4th ed. Elsevier Saunders, 2011.

4. Dermatology (Eds.: Bolognia J. L., Jorizzo J. L., Schaffer J. V.) 3rd ed. St.Louis: Mosby/Elsevier; 2012.

5. Neonatal and Infant Dermatology (Eds.: Eichenfield L. F., Frieden I. J., Zaenglein A. and Mathes E.) 3rd ed. Saunders; 2015.

6. Hotz A., Oji V., Bourrat E. és mtsai: Expanding the Clinical and Genetic Spectrum of KRT1, KRT2 and KRT10 Mutations in Keratinopathic Ichthyosis. (2016) Acta Derm.Venereol. (in press)

7. Kurosawa M., Takagi A., Tamakoshi A. és mtsai: Epidemiology and clinical characteristics of bullous congenital ichthyosiform erythroderma (keratinolytic ichthyosis) in Japan: results from a nationwide survey. J Am Acad Dermatol (2013) 68(2), 278-283.

8. Osawa R., Akiyama M. Izumi K. és mtsai.: Extremely severe palmoplantar hyperkeratosis in a generalized epidermolytic hyperkeratosis patient with a keratin 1 gene mutation. J Am Acad Dermatol (2011) 64(5), 991-993.

9. Scholzen T., Gerdes J.: The Ki-67 protein: from the known and the unknown. J Cell Physiol (2000) 182(3), 311-322.

Érkezett: 2016. 02. 02.

Közlésre elfogadva: 2016. 04. 17. 